\title{
DEVELOPMENT OF SEXUAL ASSERTIVENESS AND ITS FUNCTION FOR HUMAN SEXUALITY: A LITERATURE REVIEW
}

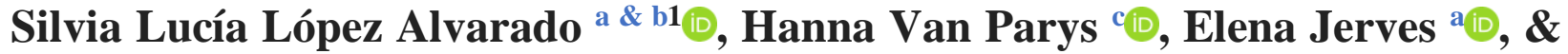 Paul Enzlin bic}

\author{
Universidad De Cuenca, Cuenca, Ecuador ${ }^{\mathrm{a}}$; KU Leuven, Leuven, België ${ }^{\mathrm{b}}$; \\ Universiteit Gent, Gent, België c.
}

\begin{abstract}
The aim of this paper was to present a literature review on sexual assertiveness (SA), on factors and life experiences that are associated with its development, and on its function in human sexuality. It was found that demographic variables (e.g., age, education, gender), sexual experiences (e.g., type of partnership, sexual victimization), psychosexual issues (e.g., sexual functioning, body self-esteem, emotion regulation, resourcefulness) and cultural factors (e.g., sexual scripts, gender stereotypes) might positively or negatively contribute to SA. Furthermore, the outcomes of SA for both individuals and intimate relationships are presented. Based on this review, it is concluded that although SA could be fostered by training programs, cultural factors still withhold many individuals from reaching a satisfactory level of SA. Finally, recommendations about how to further the study of SA are presented.
\end{abstract}

\section{Keywords}

sexual assertiveness; human sexuality; associated factors; literature review

\section{RESUMEN}

El objetivo de este estudio fue presentar una revisión de literatura sobre la asertividad sexual (AS), sobre los factores y experiencias de vida asociados con su desarrollo, y sobre su función en la sexualidad humana. Se encontró que, variables demográficas (ej. edad, educación, género), experiencias sexuales (ej. tipo de pareja, victimización sexual), aspectos psicosexuales (ej. funcionamiento sexual, autoestima con la imagen corporal, regulación de emociones, inventiva) y factores culturales (ej. guiones sexuales, estereotipos de género) podrían contribuir positiva o negativamente a la AS. Asimismo, se presentan los efectos de la AS tanto en los individuos como en las relaciones de pareja. Basados en esta revisión se concluye que, pese a que la AS puede ser entrenada, el contexto cultural aun dificulta a algunos individuos a alcanzar niveles satisfactorios de AS. Finalmente, se presentan recomendaciones sobre cómo continuar estudiando la AS.

Palabras clave

asertividad sexual; sexualidad humana; factores asociados; revisión de literatura

\footnotetext{
${ }^{1}$ Correspondence about this article should be addressed to Silvia Lucía López Alvarado: silvia.lopez@ucuenca.edu.ec

2 Acknowledgments: The funding that enabled this study was supported by the Institutional University Cooperation Programme (IUC) between the University of Cuenca (Ecuador) and the Flemish Universities through funding by the Flemish Interuniversity Council (VLIR-UOS), and also by the National Secretariat of Higher Education, Science, Technology and Innovation of Ecuador (Senescyt).

3 a. Faculty of Psychology; Faculty of Philosophy, Letters and Educational Sciences; b. Institute for Family and Sexuality Studies, Department of Neurosciences; CeKSS - Center for Clinical Sexology and Sex Therapy, UPC KU Leuven; c. Department of Psychiatry, Ghent University Hospital.
} 


\section{EL DESARROLLO DE LA ASERTIVIDAD SEXUAL Y SU FUNCIÓN PARA LA SEXUALIDAD HUMANA: UNA REVISIÓN DE LA LITERATURA}

\section{Introduction}

Sexual assertiveness (SA) has been identified as an important construct in the context of human sexuality (Santos-Iglesias \& Sierra, 2010) and is defined in various ways. These definitions comprise many elements including the ability to initiate or to refuse sexual activity with a partner, the capacity to negotiate the use of condoms or other contraceptive methods, the ability to discuss with a partner about each other's sexual history, and the communication of sexual desires and satisfaction (Loshek \& Terrell, 2014; Morokoff et al., 1997; Noar, Morokoff, \& Harlow, 2002).

Previous research has shown that SA may have positive outcomes for both individuals and their relationships. It was shown that SA positively affects the level of satisfaction with oneself as well as with a partner (Greene \& Faulkner, 2005), that it contributes to sexual functioning (Sánchez-Bravo, Morales-Carmona, Carreño-Meléndez, \& Martínez-Ramírez, 2005; SantosIglesias, Sierra, \& Vallejo-Medina, 2013), and constitutes a possible prevention strategy for unwanted pregnancies, sexually transmitted infections (STI) and sexual victimization (Livingston, Testa, \& VanZile-Tamsen, 2007; Noar, Carlyle, \& Cole, 2006; Noar et al., 2002).

The recognition of the importance of SA in human sexuality has resulted in an increased research interest in the topic that started in the 1970s (Santos-Iglesias \& Sierra, 2010). Initial research into SA viewed it as one of the overall categories of general assertiveness (Gambrill \& Richey, 1975). However, it was found that an assertive person is not necessarily assertive in a sexual context (Onuoha \& Munakata, 2005), which led to the assumption that SA is more difficult to develop than general assertiveness (Morokoff et al., 1997; Noar et al., 2002). Since the 1990s, more studies have focused on sexual assertiveness as a construct in its own right and have attempted to better understand it (Loshek \& Terrell, 2014; Morokoff et al., 1997).

Moreover, based on the positive outcomes of SA, it is suggested that further study into SA will be helpful in unravelling the reasons behind unwanted and unsafe sexual activities. This might be especially important in social contexts in which, as a result of cultural norms, indicators of sexual and reproductive health are problematic, i.e., having to consent to unwanted sexual intercourse (Bay-Cheng \& Eliseo-Arras, 2008) because one is not able to refuse (Santos-Iglesias, Vallejo-Medina, \& Sierra, 2013).

Previous studies have suggested that SA is developed throughout the life of a person and is seemingly due to a combination of facilitating and inhibiting factors (Zerubavel \& Messman- 
Moore, 2013). However, studies suggest that there are conceptual differences in SA across sociocultural contexts, highlighting the importance of taking contextual factors into account when studying SA (Yoshioka, 2000).

Historically, most studies have focused on understanding the importance of SA in human sexuality both theoretically (Santos-Iglesias \& Sierra, 2010) and empirically (Greene \& Faulkner, 2005; Morokoff et al., 1997; Santos-Iglesias et al., 2013). While this approach has led to a good foundation in understanding SA, a broader, more global understanding of the development of SA in both sexes that takes into account the associated factors and cultural context is needed. The aim of this paper is to present a literature review on sexual assertiveness (SA), on factors and life experiences that are associated with its development, and on its function in human sexuality.

\section{Method}

\section{Article Retrieval}

To find relevant sources pertaining to SA, a search for scientific articles was conducted using the search engines PubMed, Limo and Google Scholar. The following keywords were included: (Sexual) Assertiveness, Negotiation Strategies, Communication, Sexual Agency, and the Spanish term Asertividad Sexual. These keywords also brought up other key words related to the topic, and facilitated the retrieval of relevant literature.

\section{Inclusion criteria}

Scientific articles were included if they were: (1) published in an English or Spanish peerreviewed journal; (2) based on an empirical study on sexual assertiveness or any of its associated factors; and (3) published in the last 15 years. Studies that were published more than 15 years ago were only included when they were frequently mentioned in the literature and were presented as important to the field, i.e. authors that made important contributions and articles containing information on useful instruments that are relevant to empirically studying SA (Appendix 1).

\section{Results}

\section{Characteristics of the studies}

In total, 46 scientific articles (see Table 1) met the inclusion criteria and a content analysis revealed that they covered several topics related to SA; including cultural context, sexual experiences and psychosexual factors. The majority of articles $(n=33 ; 71.73 \%)$ had SA as their 
primary focus. The inclusion of articles that featured SA as a secondary or tertiary focus allowed for a more contextualized understanding of the dynamics related to SA.

Most studies were conducted in the United States of America (USA) (n=29; 63.04\%), but others were from Europe $(n=6 ; 13.04 \%)$, Canada $(n=6 ; 13.04 \%)$, and South America $(n=3 ; 6.52 \%)$, as well as cross-cultural studies conducted in China, Japan, Thailand and various African nations $(\mathrm{n}=2 ; 4.34 \%)$. It is important to mention that although most studies were conducted in the USA, samples often included migrants, mostly from Latin America.

The majority of research $(n=34,73.91 \%)$ used a quantitative methodology including surveys, questionnaires and validated scales, and aimed to explore how SA was influenced by variables such as victimization experiences, gender roles, and psychosexual factors. Other authors focused on the development and validation of scales to evaluate different aspects of SA (Loshek \& Terrell, 2014; Morokoff et al., 1997). Finally, there were some intervention studies that aimed to evaluate the impact of training programs on levels of sexual assertiveness in certain populations.

\section{Findings}

The results of this review revealed that SA is influenced by a combination of several aspects. The importance of and extent to which each aspect influences SA is presented around the description of several topics, i.e., demographic characteristics, cultural context, sexual experiences, and psychosexual factors.

\section{Demographic characteristics}

As presented below, demographic characteristics, such as age, education and gender, have been shown to be associated with the development of SA.

Age

Although SA can develop throughout one's life, there are key periods in which this development is most likely to occur and thus, deserved research attention. During adolescence and emerging adulthood, romantic relationships and sexual activity are normative. This means that this is an important key period for both sexes to develop the necessary skills to attain a healthy sexual life (Shulman \& Connolly, 2013; Manlove, Franzetta, Ryan, \& Moore, 2006). Therefore, in these 
periods there is a need to understand the various types of relationships individuals have (Kan \& Cares, 2006), but also how they transition from being single (individualistic processes) to becoming a couple (dyadic processes) (Shulman \& Connolly, 2013). In this period, challenges to the development of SA are related to a lack of experience in negotiating sexual activity (Beres, 2010), a low awareness of their sexual and reproductive rights (Rickert, Sanghvi, \& Wietmann, 2002), and an increased vulnerability to act under pressure (e.g., comply in unwanted sexual activities to keep their partner) (Bay-Cheng \& Eliseo-Arras, 2008). Additionally, in an effort to have a 'successful' relationship, individuals at this age often put their partner's needs before their own, even if this may be detrimental to their own physical and mental health (Rickert et al., 2002).

\section{Education}

Level of education was considered in some studies as this element also typically increases with age. A study comparing graduate and undergraduate female students found an association between higher levels of education and greater SA (Rodriquez, Johnson, \& Combs, 2001). In addition to the level of education, it is also important to take into account the exposure, or lack thereof, to sex education programs that stimulate the development of SA in individuals. Hirst (2008) highlighted the importance of sex education and training programs in improving factors that have an impact on the contexts, motivations and outcomes of sexual encounters and therefore have implications for SA. Importantly, there are dimensions of SA that are more easily fostered by training programs, such as a sense of empowerment and self-efficacy to resist pressure from a sexual partner to have sexual intercourse (Kelley, Orchowski, \& Gidycz, 2016).

\section{Gender}

There are specific gender-based norms that influence sexual behavior in intimate relationships and these norms are discussed in some studies on SA. Men and women seem to assert their sexual thoughts in different ways (Santos-Iglesias et al., 2013). Research has shown that men and women are expected to derive their specific roles from social scripts and that they act in accordance with these gendered standards (Fetterolf \& Sanchez, 2015). Social scripts for men often include seeking pleasure and fun, and so they should regularly initiate sexual intercourse (Manago, Ward, \& Aldana, 2015; Vannier \& O’Sullivan, 2011), whereas scripts for women regarding sex 
refer to love and affection, and, as 'gatekeepers of sex', women need to develop skills to refuse and prevent sexual intercourse (Bourdeau, Thomas, \& Long, 2008; Manago, Ward \& Aldana, 2015; Santos-Iglesias et al., 2013). Given the importance of gender scripts in SA, it is necessary to consider the current differences, but also how they can be changed and adapted in the modern era. An important new challenge is to study how social media and an online 'messages' affect the development of SA in women and men (Manago, Ward, Lemm, Reed, \& Seabrook, 2015).

\section{Cultural context}

The premise that cultural context shapes sexual behavior informs the idea that the development of SA in men and women is, in part, the result of gender dynamics in a society. It is important to take into account that cultural context varies widely and that many groups have their own perceptions of what SA means and how it is tied to different codes and values (Yoshioka, 2000; Rickert et al., 2002). Cross-cultural studies that have evaluated the levels of SA between cultures have concluded that women and men living in Western, i.e., European and North American, cultures - also known as individualistic societies - show higher levels of SA compared to those living in Eastern, i.e., Asian, and Latin American cultures - also known as collectivistic societies (Rodriquez et al., 2001; Yoshioka, 2000).

In a broad conceptual sense, cultural context operates by giving 'standards of normality' which in turn result in dominant specific gender ideologies (Fetterolf \& Sanchez, 2015; Manago, Ward \& Aldana, 2015; Tolman, Davis, \& Bowman, 2016; Vannier \& O’Sullivan, 2011). Thus, to explain gender ideologies, the literature highlights the role of sexual scripts that are present in all cultures and are a result of established cultural and moral values. In the specific case of Latin American cultures, the literature also addresses the predominance of rigid gender stereotypes also known as machismo, marianismo and familismo (Goicolea, Torres, Edin, \& Öhman, 2012; Manago, Ward \& Aldana, 2015).

\section{Sexual scripts}

Sexual behavior is the result of cognitive models - also known as sexual scripts - that organize the understanding of certain situations and drive individuals' behavior (Simon \& Gagnon, 2003). Sexual scripts refer to actions that are appropriate in certain situations and guide 
individuals' thoughts before taking action. These scripts lead to a permanent evaluation of one's behavior based on the learned roles that differ for men and women (Greene \& Faulkner, 2005).

It has been shown that less adherence to traditional sexual scripts leads to more discussions between partners about sexual activities, although this did not influence efficacy to request certain sexual behavior (Greene \& Faulkner, 2005). Moreover, it has been suggested that 'traditional' scripts are still predominant for women and especially in Latin American cultures. In Latin American cultures women are expected to be passive, submissive and non-assertive, and to demonstrate desire for affection and love, rather than for sex. In contrast, men are expected to be aggressive, emotional, intensive, and uncontrollable when they are sexually aroused. It is expected that men are the ones who will initiate sex and that it will be focused on conquest and seeking pleasure for themselves (Castillo, Perez, Castillo, \& Ghosheh, 2010; Goicolea et al., 2012). Given the societal pressure to conform to these scripts, gender stereotypes and a sexual double standard are reinforced, clearly highlighting a disparity for what is considered acceptable behavior for both sexes (Manago, Ward \& Aldana, 2015).

\section{Gender stereotypes}

Gender stereotypes are a combination of personality traits, attitudes, values, and behaviors that characterize the social expectations of men and women (Sánchez-Bravo et al., 2005). In general, most cultures differ in terms of the social expectations for men and women concerning behavior in sexual situations (Tolman et al., 2016). In Latin American cultures, these social expectations are quite conservative. For a Latin woman, it is difficult to openly speak about her sexual desire with her partner, and, in some cases, even acknowledging her sexual desire might be an issue (Impett, Schooler, \& Tolman, 2006). In contrast, Latin men are expected to be open about their sexual desires and to initiate sexual activity (Manago, Ward \& Aldana, 2015). When analyzing gender stereotypes in Latin American cultures, it is important to consider the moral codes, machismo and marianismo, and their reinforcement by the system of familismo, as they play a significant role in the sexual expectation of men and women (Castillo et al., 2010).

Machismo refers to a gender stereotyped role in which virility is mainly based on an exaggerated role of masculinity and power exerted by men, particularly to dominate women in the context of intimate relationships (Arciniega, Anderson, Tovar-Blanc, \& Terrence, 2008). This concept is often related to a kind of male power that drives all masculine behaviors and reinforces 
the idea that a man is allowed to guide the relationship, especially with regard to sexual activities (Sastre et al., 2015).

Marianismo is the cultural counterpart of machismo and defines the stereotyped gender role of women within Latin society. This moral code emphasizes the spiritual superiority of women over men, as shown in qualities such as modesty, devotion, chastity, and virginity. Moreover, this concept leads to a cultural image of a woman as a familiar and spiritual pillar and the one who stays silent and submissive (Castillo et al., 2010).

Machismo and marianismo are reinforced by familismo which is a well-known belief system that characterizes Latin American families (Manago, Ward \& Aldana, 2015). Familismo refers to the identification, or extension of oneself, that an individual might have within their family (Raffaelli \& Ontai, 2004). It implies having respect for, and submitting to others, particularly to figures of authority such as older people, parents, men and husbands. This often dictates that women take on a subordinate position within the dynamic of a family (Castillo \& Cano, in Castillo et al., 2010). It is assumed then that within this concept, a woman's behavior should be a reflection of the norms that were taught in the home.

Machismo, marianismo and familismo are considered important barriers for the development of SA within intimate relationships due to the opposite expectations that these stereotypes prescribe for both genders (Bourdeau et al., 2008). These expectations are particularly marked when considering the initiation of sex: men feel that they are expected to initiate sex (Vannier \& O’Sullivan, 2011), whereas women report not having control over sexual encounters as they feel that they must wait to be 'seduced' by their male partner (Goicolea et al., 2012). This sentiment is also echoed when it comes to contraception. Sastre et al. (2015) suggest that the use of condoms for safe sex is typically under the control of the man, whereas when a woman insists on using condoms, it is often interpreted as mistrust or even an indication of promiscuity (Greene \& Faulkner, 2005).

\section{Sexual experiences}

Another factor associated with the development of an individual's SA is one's sexual experiences either as a child, an adolescent, or an adult. Every element that constitutes sexual experience plays an important role, acting either as a barrier or a facilitator in the development of SA. Elements related to sexual experiences that are found to be associated with SA are presented 
below (Morokoff et al., 1997; Beres, 2010; Santos-Iglesias \& Sierra, 2012; Kennett, Humphreys, \& Schultz, 2012; Zerubavel \& Messman-Moore, 2013).

\section{Type of partnership}

The impact of type of partnership has received increased attention since research has shown that the levels of SA might differ in an individual when they move from one partner to another (Morokoff et al., 1997). As intimate relationships differ depending on the type of partnership, the dynamic and quality of each relationship can have a varying influence on an individual's SA (Morokoff et al., 1997). Despite the varied types of partnerships, two elements were identified as strong determinants for SA in most sexual relationships.

First, the initial stages of a relationship are typically characterized by greater difficulties regarding communication, as the individuals have not been exposed to each other very long and do not know each other very well. This feeling abates over time as confidence grows when more time is spent with each other (Kitzinger \& Frith, 1999). It is important that in the early stages of a relationship, both partners learn how to communicate with each other and build a cognitive model of each other's responses (Beres, 2010) which means with time, an individual knows what to expect from the partner.

Second, the other strong determinant of SA is sexual experience and the number of previous partners. This is particularly relevant for women, although evidence from review is conflicting. On one hand, when it comes to initiating sexual activities, sexually experienced women have been found to be more assertive in comparison with less experienced women (Rickert et al., 2002), however, women with more previous sexual partners have been found to have more difficulties refusing sexual activity and implementing prevention strategies (Auslander, Perfect, Succop, \& Rosenthal, 2007).

\section{Sexual Victimization}

Sexual victimization refers to any violent or coercive experience, including cuddling, fondling, kissing, and in several cases rape and incest, for which physical force, authority, or difference in age is used as a mechanism to dominate another person (Greene \& Navarro, 1998, in Santos-Iglesias \& Sierra, 2012). While this phenomenon occurs in both genders and across all 
ages, higher incidences are reported by women, children and adolescents (Morokoff et al., 2009). It is also important to note that sexual victimization also includes consenting to unwanted sexual activity with a partner (Kennett, Humphreys, \& Schultz, 2012).

According to the literature, the relationship between sexual victimization and the development of SA is reciprocal (Livingston et al., 2007). Individuals affected by sexual victimization may have difficulties initiating and controlling sexual activities, and negotiating the use of condoms (Morokoff et al., 2009; Santos-Iglesias \& Sierra, 2012; Rickert, et al., 2002). This can lead to the possibility of further victimization, known as re-victimization. Subsequent experiences of sexual victimization are a well-known characteristic of early victimization (Kelley et al., 2016). Conversely, SA was found to be a particularly salient mediator for sexual victimization in women (Kelley et al., 2016; Livingston et al., 2007). It has been found that individuals that had previously experienced sexual victimization were better able to adapt to possible detrimental encounters, specifically when it comes to refusing to have sexual intercourse (Schry \& White, 2013).

\section{Psychosexual factors}

Despite the challenges of determining a consistent model that predicts the development of SA, several studies have shown that SA is, among other aspects, strongly associated with psychosexual factors. These include, sexual function (Santos-Iglesias et al., 2013; Leclerc et al., 2015), body positivity and self-esteem (Auslander, Baker, \& Short, 2012), the regulation of emotions (Zerubavel \& Messman-Moore, 2013) and mechanisms of resourcefulness (Humpreys \& Kennett, 2010). It is important to note that although these factors can all be considered important in the development of SA, they may have varying impact depending on the individual and can act independently of one another.

\section{Sexual functioning}

As SA constitutes an important component of human sexuality, several studies have found correlations between elements of sexual function, such as sexual arousal, sexual desire, and sexual fantasies and SA (Santos-Iglesias et al., 2013; Torres-Obregon, Onofre-Rodríguez, Sierra, Benavides-Torres, \& Garza-Elizondo, 2017). A positive link between sexual function and SA is clear when considering erotophilic individuals, i.e., those who have positive attitudes towards 
sexuality, and whose sexual ideals and responses facilitate the development of SA, particularly when it comes to initiation and refusal (Santos-Iglesias et al., 2013). When considering the relationship between sexual function and SA, however, it is important to consider and include sexual dysfunction, as this can have a significant impact on SA (Leclerc et al., 2015; SánchezBravo et al., 2005). A recent study of women with experienced vestibulodynia, a condition that causes pain at the vaginal opening, found that women with higher levels of SA were better able to communicate with their partners about sexual choices and preferences for sexual activities (McNicoll, Corsini-Munt, Rosen, McDuff, \& Bergeron, 2016).

\section{Body self-esteem}

Body self-esteem refers to the evaluation individuals make about their own body (Auslander et al., 2012). This psychosexual factor has been found to be important for SA, specifically regarding the use of condoms and other contraceptive methods. The way body selfesteem operates on an individual level is related to increased body satisfaction, which lays the foundations for things such as the correct negotiation of the use of condoms (Auslander et al., 2012). Given the prevalence of social media in modern society and the veneration of body image and aesthetics that it cultivates, it is important to consider the effect it has on body positivity and self-esteem. A recent study found that Facebook involvement increases objectified body consciousness and can affect the SA of an individual positively, by increasing someone's selfesteem, or negatively, by fostering feelings of shame about their body (Manago et al., 2015).

\section{Emotion regulation}

Emotion regulation refers to an individual's ability to acknowledge and regulate emotions and feelings that may positively influence sexual responses (Zerubavel \& Messman-Moore, 2013). To regulate an appropriate response, individuals must be aware of, understand, and accept their

own emotions. Individuals who are capable of satisfactory emotion regulation are more likely to communicate to their partner both verbally and non-verbally in a direct and assertive way (Gratz \& Roemer, 2004; Zerubavel \& Messman-Moore, 2013). Research has found that emotion regulation is particularly associated with SA when it comes to initiation and refusal of sexual 
intercourse due to the sense of empowerment and agency an individual may feel (Zerubavel \& Messman-Moore, 2013).

\section{Resourcefulness}

In the context of SA, resourcefulness is the ability to resist pressure from a partner to participate in unwanted sexual activities: the ability of an individual to say 'no' or to leave a pressured situation (Humphreys \& Kennett, 2010). This is achieved through the use of positive self-instructions, problem-solving methods, and delay of gratification (Kennett et al., 2012; Humphreys \& Kennett, 2010). To utilize such strategies, an individual must be able to rely on high levels of self-control, learn appropriate behaviors and responses applicable to specific situations, and be able to rely on coping strategies when problematic situations or negative emotions occur. Resourcefulness is clearly an important facilitator for the development of SA when it comes to the use of negotiation strategies and resistance to external pressure (Kennett et al., 2012; Humphreys \& Kennett, 2010).

\section{Outcomes of Sexual Assertiveness}

While the factors mentioned above have a clear impact on the development of SA, it is important to highlight three main outcomes for sexuality that were consistently described throughout the literature reviewed.

Impact on the level of satisfaction within the intimate relationship

Given the importance of communication in intimate relationships, several studies have suggested that asserting and controlling desired sexual activities has a positive influence on both satisfaction within relationships (Leclerc et al., 2015; McNicoll et al., 2016; Noar et al., 2002) and overall sexual satisfaction (Ménard \& Offman, 2009). SA is considered key to achieve a good sexual life as it allows the needs of the individual and their partner to be met. Furthermore, McNicoll et al. (2016) found that SA is positively associated with perceived 'facilitative,' i.e., encouraging, affectional, and positive, responses. 
Sexual assertiveness as a protective factor for unwanted pregnancies and STIs.

Despite the increasing quality and quantity of information available, and efforts to prevent unwanted pregnancies and STIs, there are still barriers for women to negotiate about the use of condoms for safe sex (Noar et al., 2006). Traditionally, men are considered to be responsible for carrying condoms and for expressing the necessity to use them (Noar et al., 2002; Sastre et al., 2015), whereas women may feel that it is easier to engage in unwanted pregnancies, rather than openly discuss their desires (Bay-Cheng \& Eliseo-Arras, 2008). Negotiation about condom use by both men and women should include inquiring about a partner's sexual history, so as to be able to estimate the potential risks of a sexual encounter (Greene \& Faulkner, 2005). SA is considered the best predictor for the use of contraceptive methods, particularly condoms, as low levels of SA are related to inconsistent use of contraceptive methods (Noar et al., 2006, 2002).

\section{Protective factor against victimization.}

SA is seen as a central component in the prevention of sexual victimization (Kelley et al., 2016; Zerubavel \& Messman-Moore, 2013). Any type of abuse, trauma or sexual victimization, particularly a history of child sexual abuse, negatively interferes with the development of SA and the likelihood of experiencing victimization or re-victimization is increased when an individual's SA is low (Livingston et al., 2007; Rickert et al., 2002). In contrast, a high level of SA might constitute one of the protective factors against future sexual victimization (Kelley et al., 2016).

\section{Discussion}

The aim of this paper was to present a literature review on sexual assertiveness (SA) and factors and life experiences that are associated with its development, and function in human sexuality. The results of this review revealed that SA is the result of a combination of several aspects. Sexual agency, which refers to an individual's inner notions about their own sexual needs and desires (Fetterolf \& Sanchez, 2015) was found to influence SA. The development of SA is also the result of the balance between barriers and facilitating factors (Zerubavel \& MessmanMoore, 2013). It is clear that demographic characteristics, cultural context, previous sexual experiences, and psychosexual factors may all influence SA. These associated factors influence SA by either facilitating positive practices or by acting as a barrier for the development of SA. 
Yet, not all of the mentioned factors may equally influence the multiple dimensions of this construct (Auslander et al., 2012, 2007).

This review also confirmed the relevance of SA already described in previous studies (Santos-Iglesias \& Sierra, 2010) such as (1) its positive impact on satisfaction within an intimate relationship (Leclerc et al., 2015; McNicoll et al., 2016; Noar et al., 2002); (2) its protective qualities against unwanted pregnancies and STI's; and (3) its ability to reduce the chance of new or repeated sexual victimization (Livingston et al., 2007; Noar et al., 2006; Zerubavel \& MessmanMoore, 2013). Thus, SA is a fundamental element for sexual function and response as it facilitates positive, satisfying, and healthy sexual interactions. In addition to this, SA is also potentially an important protective factor against risky sexual activities and victimization experiences.

Undoubtedly, one of the most relevant findings of this review was the influence that cultural context has on the development of SA, through the presence of sexual scripts and gender stereotypes. When evaluating the SA of an individual, it is important to consider the cultural context that has influenced their life (Yoshioka, 2000; Rickert et al., 2002). As previously described, in Latin American cultures, higher levels of SA may be difficult, particularly for women. Despite differences across cultures, in general and globally women are more restricted by cultural norms and expectations than men (Bourdeau et al., 2008). Studies conducted in Latin America suggested that women are less sexually assertive than men, but this seems the result of cultural factors that shape and script their position and prescribe non-assertive behavior in relationships. In contrast, scripts for Latin American men allow for higher levels of sexual assertiveness and it is more culturally appropriate for them to express their sexual desire and to initiate sexual activity (Fetterolf \& Sanchez, 2015; Manago, Ward, \& Aldana, 2015). It can be concluded that, particularly in Latin American cultures, cultural context may result in a conflict between personal motivations and social expectations, but also between the importance of collectivism over individualism (Yoshioka, 2000). SA is considered to be a better fit in individualistic societies where cultural norms are predominantly focused on the needs, thoughts, and feelings of the individual and less on the family or the broader community (Castillo et al., 2010; Manago, Ward, \& Aldana, 2015).

Apart from the impact of cultural context, this review also highlights the reciprocal relationship between previous sexual experiences and the development of SA. This implies that one's sexual experiences influence the development of sexual assertiveness, but also that one's 
level of sexual assertiveness predicts future sexual experiences in either a positive or negative way (Livingston et al., 2007).

While there is a clear understanding of the role of cultural patterns and sexual experiences in the development of SA, Santos-Iglesias \& Sierra (2012) have posited that defining a consistent model to predict the development of SA is challenging. This review highlights that most studies have focused on separate psychosexual factors such as sexual functioning, body image, selfesteem, resourcefulness, and emotion regulation, without necessarily attempting to integrate these in a broader theoretical framework.

This review further revealed that the study of SA is a developing field with several possible avenues for future research. First, given the association between SA and cultural patterns, conducting future research using qualitative methods might yield more information about the role SA plays in intimate relationships and allow us to gain a better understanding of the sexual double standard (Bourdeau et al., 2008; Fetterolf \& Sanchez, 2015). This will be particularly pertinent for future studies in Latin American countries, where the gender stereotypes of machismo, marianismo and familismo clearly have a significant impact on an individual's sexual life (Bourdeau et al., 2008). However, caution should be used, as formulated by Loshek \& Terrell (2014), who suggested that the traditional gender stereotypes may not apply equally to all dimensions of SA.

As most research is based on a variety of scales to measure SA, it is suggested that there is a need for a more comprehensive measurement of SA that includes all the theoretical elements discussed in this review. While the new scale proposed by Loshek and Terrell (2014) is promising, it needs to be further tested and validated in more studies before its value can be ascertained.

Future studies should focus on the importance of SA in intimate relationships, as it is evident that higher levels of SA translate into an increased likelihood of achieving personal goals during intimate interactions. When both partners are equally assertive there is greater chance that their own sexual goals will be adequately represented and/or achieved. As sexual relationships involve two people who may have their own levels of SA, studies should evaluate the SA of both partners and not just focus on women, as the majority of studies have done until now. The outcomes of this literature review should be interpreted taking into account some limitations. First, given the limited amount of information available, this review is rather descriptive, as the information did not allow for a more thorough integrated analysis. Second, the limited available information implies that the studies used in this review might be biased, as the retrieval of new 
articles was often informed by the suggestions for further reading from other studies. Lastly, as the literature review findings mostly show the complexity of the Latin American context for the development of SA in women, further studies that include a broader range of cultures would be advantageous, as this would improve our understanding of the impact that different cultures have on SA.

In conclusion, SA is clearly relevant in human sexuality on an individual level, by enabling individuals to express their preferences in a relational context, and on a societal level, given its role in protection against sexual coercion. SA seems to be the outcome of developmental processes and the result of a combination of facilitating and inhibiting demographic and psychosexual factors. Cultural determination of SA was a pivotal theme in this review, which not only highlighted findings on the development of SA, but also that there are still important gaps in our understanding of this interesting and important topic. 


\section{References}

Arciniega, M., Anderson, T., Tovar-Blanc, Z., \& Terrence, T. (2008). Toward a Fuller Conception of Machismo: Development of a Traditional. Journal of Counseling Psychology, 55(1), 1933.

Auslander, B. A., Baker, J., \& Short, M. B. (2012). The Connection between Young Women's Body Esteem and Sexual Assertiveness. Journal of Pediatric and Adolescent Gynecology, 25(2), 127-130. https://doi.org/10.1016/j.jpag.2011.11.008

Auslander, B. A., Perfect, M. M., Succop, P. A., \& Rosenthal, S. L. (2007). Perceptions of Sexual Assertiveness among Adolescent Girls: Initiation, Refusal, and Use of Protective Behaviors. Journal of Pediatric and Adolescent Gynecology, 20(3), 157-162. https://doi.org/10.1016/j.jpag.2007.03.093

Bay-Cheng, L. Y., \& Eliseo-Arras, R. K. (2008). The Making of Unwanted Sex: Gendered and Neoliberal Norms in College Women's Unwanted Sexual Experiences. The Journal of Sex Research, 45(4), 386-397. https://doi.org/10.1080/00224490802398381

Beres, M. (2010). Sexual miscommunication? Untangling assumptions about sexual communication between casual sex partners. Culture, Health \& Sexuality, 12(1), 1-14.

Bourdeau, B., Thomas, V. K., \& Long, J. K. (2008). Latino Sexual Styles: Developing a Nuanced Understanding of Risk. The Journal of Sex Research, 45(1), 71-81. https://doi.org/10.1080/00224490701845185

Castillo, L. G., Perez, F. V., Castillo, R., \& Ghosheh, M. R. (2010). Construction and initial validation of the Marianismo Beliefs Scale. Counselling Psychology Quarterly, 23(2), 163-175. https://doi.org/10.1080/09515071003776036

Fetterolf, J. C., \& Sanchez, D. T. (2015). The costs and benefits of perceived sexual agency for men and women. Archives of Sexual Behavior, 44(4), 961-970.

Gambrill, E. D., \& Richey, C. A. (1975). An assertion inventory for use in assessment and research. Behavior Therapy, 6(4), 550-561. https://doi.org/10.1016/S0005-7894(75)80013-X

Goicolea, I., Torres, M. S., Edin, K., \& Öhman, A. (2012). When Sex is Hardly About Mutual Pleasure: Dominant and Resistant Discourses on Sexuality and its Consequences for Young People's Sexual Health. International Journal of Sexual Health, 24(4), 303-317. https://doi.org/10.1080/19317611.2012.715121

Gratz, K. L., \& Roemer, L. (2004). Multidimensional Assessment of Emotion Regulation and Dysregulation: Development, Factor Structure, and Initial Validation of the Difficulties in Emotion Regulation Scale. Journal of Psychopathology and Behavioral Assessment, 26(1), 41-54. https://doi.org/10.1023/B:JOBA.0000007455.08539.94

Greene, K., \& Faulkner, S. L. (2005). Gender, Belief in the Sexual Double Standard, and Sexual Talk in Heterosexual Dating Relationships. Sex Roles, 53(3-4), 239-251. https://doi.org/10.1007/s11199-005-5682-6

Hirst, J. (2008). Developing sexual competence? Exploring strategies for the provision of effective sexualities and relationships education. Sex Education, 8(4), 399-413. https://doi.org/10.1080/14681810802433929

Humphreys, T. P., \& Kennett, D. J. (2010). The reliability and validity of instruments supporting the sexual self-control model. The Canadian Journal of Human Sexuality; Toronto, 19(1/2), 1-13.

Impett, E. A., Schooler, D., \& Tolman, D. L. (2006). To Be Seen and Not Heard: Femininity Ideology and Adolescent Girls' Sexual Health. Archives of Sexual Behavior, 35(2), 129142. https://doi.org/10.1007/s10508-005-9016-0 
Kan, M. L., \& Cares, A. C. (2006). From "friends with benefits" to "going steady": new directions in understanding romance and sex in adolescence and emerging adulthood. En A. C. Crouter, \& A. Booth (Eds.), Romance and Sex in Adolescence and Emerging Adulthood, risks and opportunities (pp. 241-256). New York, London: Lawrence Erlbaum Associates.

Kelley, E. L., Orchowski, L. M., \& Gidycz, C. A. (2016). Sexual victimization among college women: Role of sexual assertiveness and resistance variables. Psychology of Violence, 6(2), 243-252. https://doi.org/10.1037/a0039407

Kennett, D. J., Humphreys, T. P., \& Schultz, K. E. (2012). Sexual resourcefulness and the impact of family, sex education, media and peers. Sex Education, 12(3), 351-368. https://doi.org/10.1080/14681811.2011.615624

Kitzinger, C., \& Frith, H. (1999). Just Say No? The Use of Conversation Analysis in Developing a Feminist Perspective on Sexual Refusal. Discourse \& Society, 10(3), 293-316. https://doi.org/10.1177/0957926599010003002

Leclerc, B., Bergeron, S., Brassard, A., Bélanger, C., Steben, M., \& Lambert, B. (2015). Attachment, Sexual Assertiveness, and Sexual Outcomes in Women with Provoked Vestibulodynia and Their Partners: A Mediation Model. Archives of Sexual Behavior, 44(6), 1561-1572. https://doi.org/10.1007/s10508-014-0295-1

Livingston, J. A., Testa, M., \& VanZile-Tamsen, C. (2007). The Reciprocal Relationship Between Sexual Victimization and Sexual Assertiveness. Violence Against Women, 13(3), 298-313. https://doi.org/10.1177/1077801206297339

Loshek, E., \& Terrell, H. K. (2014). The Development of the Sexual Assertiveness Questionnaire (SAQ): A Comprehensive Measure of Sexual Assertiveness for Women. The Journal of Sex Research, O(0), 1-11. https://doi.org/10.1080/00224499.2014.944970

Manago, A. M., Ward, L. M., \& Aldana, A. (2015). The Sexual Experience of Latino Young Adults in College and Their Perceptions of Values About Sex Communicated by Their Parents and Friends. Emerging Adulthood, 3(1), 14-23. https://doi.org/10.1177/2167696814536165

Manago, A. M., Ward, L. M., Lemm, K. M., Reed, L., \& Seabrook, R. (2015). Facebook Involvement, Objectified Body Consciousness, Body Shame, and Sexual Assertiveness in College Women and Men. Sex Roles, 72(1-2), 1-14. https://doi.org/10.1007/s11199-0140441-1

Manlove, J., Franzetta, K., Ryan, S., \& Moore, K. (2006). Adolescent Sexual Relationships, contraceptive consistency, and pregnancy prevention approaches. En A. C. Crouter, \& A. Booth (Eds.), Romance and Sex in Adolescence and Emergind Adulthood, risks and opportunities (p. 181-212). New York, London: Lawrence Erlbaum Associates.

McNicoll, G., Corsini-Munt, S., Rosen, N. O., McDuff, P., \& Bergeron, S. (2016). Sexual Assertiveness Mediates the Associations Between Partner Facilitative Responses and Sexual Outcomes in Women With Provoked Vestibulodynia. Journal of Sex \& Marital Therapy, O(0), 1-15. https://doi.org/10.1080/0092623X.2016.1230806

Ménard, A. D., \& Offman, A. (2009). The interrelationships between sexual self-esteem, sexual assertiveness and sexual satisfaction. The Canadian Journal of Human Sexuality; Toronto, $18(1 / 2), 35-45$.

Morokoff, P. J., Quina, K., Harlow, L. L., Whitmire, L., Grimley, D. M., Gibson, P. R., \& Burkholder, G. J. (1997). Sexual Assertiveness Scale (SAS) for women: Development and validation. Journal of Personality and Social Psychology, 73(4), 790-804. https://doi.org/10.1037/0022-3514.73.4.790 
Morokoff, P. J., Redding, C. A., Harlow, L. L., Cho, S., Rossi, J. S., Meier, K. S., Brown-Peterside, P. (2009). Associations of Sexual Victimization, Depression, and Sexual Assertiveness with Unprotected Sex: A Test of the Multifaceted Model of HIV Risk Across Gender. Journal of Applied Biobehavioral Research, 14(1), 30-54. https://doi.org/10.1111/j.17519861.2009.00039.x

Noar, S. M., Carlyle, K., \& Cole, C. (2006). Why Communication Is Crucial: Meta-Analysis of the Relationship Between Safer Sexual Communication and Condom Use. Journal of Health Communication, 11(4), 365-390. https://doi.org/10.1080/10810730600671862

Noar, S. M., Morokoff, P. J., \& Harlow, L. L. (2002). Condom Negotiation in Heterosexually Active Men and Women: Development and Validation of a Condom Influence Strategy Questionnaire. Psychology \& Health, 17(6), 711-735. https://doi.org/10.1080/0887044021000030580

Onuoha, F. N., \& Munakata, T. (2005). Correlates of Adolescent Assertiveness with Hiv Avoidance in a Four-Nation Sample. Adolescence; Roslyn Heights, 40(159), 525-532.

Raffaelli, M., \& Ontai, L. L. (2004). Gender Socialization in Latino/a Families: Results from Two $\begin{array}{lllll}\text { Retrospective } & \text { Studies. } & \text { Sex } & \text { Roles, }\end{array}$ https://doi.org/10.1023/B:SERS.0000018886.58945.06

Rickert, V. I., Sanghvi, R., \& Wiemann, C. M. (2002). Is Lack of Sexual Assertiveness among Adolescent and Young Adult Women a Cause for Concern? Perspectives on Sexual and Reproductive Health, 34(4), 178-183. https://doi.org/10.2307/3097727

Rodriquez, G., Johnson, S. W., \& Combs, D. C. (2001). Significant Variables Associated with Assertiveness Among Hispanic College Women. Journal of Instructional Psychology; Milwaukee, Wis., 28(3). Retrieved from https://search.proquest.com/docview/1416363519?pq-origsite=gscholar

Sánchez-Bravo, C., Morales-Carmona, F., Carreño-Meléndez, J., \& Martínez-Ramírez, S. (2005). Disfunción sexual femenina su relación con el rol de género y la asertividad. Perinatología y Reproducción Humana, 19(3-4), 152-160.

Santos-Iglesias, P., \& Sierra, J. C. (2010). El papel de la asertividad sexual en la sexualidad humana: una revisión sistemática. International Journal of Clinical and Health Psychology, 10(3), 553-577.

Santos-Iglesias, P., \& Sierra, J. C. (2012). Sexual Victimization among Spanish College Women and Risk Factors for Sexual Revictimization. Journal of Interpersonal Violence, 27(17), 3468-3485. https://doi.org/10.1177/0886260512445383

Santos-Iglesias, P., Sierra, J. C., \& Vallejo-Medina, P. (2013). Predictors of Sexual Assertiveness: The Role of Sexual Desire, Arousal, Attitudes, and Partner Abuse. Archives of Sexual Behavior, 42(6), 1043-1052. https://doi.org/10.1007/s10508-012-9998-3

Santos-Iglesias, P., Vallejo-Medina, P., \& Sierra, J. C. (2013). Equivalence and Standard Scores of the Hurlbert Index of Sexual Assertiveness Across Spanish Men and Women. Anales de Psicología / Annals of Psychology, 30(1), 232-237. https://doi.org/10.6018/analesps.30.1.143321

Sastre, F., Rosa, M. D. L., Ibanez, G. E., Whitt, E., Martin, S. S., \& O’Connell, D. J. (2015). Condom use preferences among Latinos in Miami-Dade: emerging themes concerning men's and women's culturally-ascribed attitudes and behaviours. Culture, Health \& Sexuality, 17(6), 667-681. https://doi.org/10.1080/13691058.2014.989266 
Schry, A. R., \& White, S. W. (2013). Sexual Assertiveness Mediates the Effect of Social Interaction Anxiety on Sexual Victimization Risk Among College Women. Behavior Therapy, 44(1), 125-136. https://doi.org/10.1016/j.beth.2012.09.001

Shulman, S., \& Connolly, J. (2013). The Challenge of Romantic Relationships in Emerging Adulthood: Reconceptualization of the Field. Emerging Adulthood, 1(1), 27-39. https://doi.org/10.1177/2167696812467330

Simon, W., \& Gagnon, J. H. (2003). Sexual Scripts: Origins, Influences and Changes. Qualitative Sociology, 26(4), 491-497. https://doi.org/10.1023/B:QUAS.0000005053.99846.e5

Tolman, D. L., Davis, B. R., \& Bowman, C. P. (2016). "That's Just How It Is": A Gendered Analysis of Masculinity and Femininity Ideologies in Adolescent Girls' and Boys' Heterosexual Relationships. Journal of Adolescent Research, 31(1), 3-31. https://doi.org/10.1177/0743558415587325

Torres-Obregon, R., Onofre-Rodríguez, D. J., Sierra, J. C., Benavides-Torres, R. A., \& GarzaElizondo, M. E. (2017). Validación de la Sexual Assertiveness Scale en mujeres mexicanas. Suma Psicológica, 24(1), 34-41. https://doi.org/10.1016/j.sumpsi.2017.01.001

Vannier, S. A., \& O’Sullivan, L. F. (2011). Communicating Interest in Sex: Verbal and Nonverbal Initiation of Sexual Activity in Young Adults' Romantic Dating Relationships. Archives of Sexual Behavior, 40(5), 961-969. https://doi.org/10.1007/s10508-010-9663-7

Yoshioka, M. (2000). Substantive Differences in the Assertiveness of Low-Income African American, Hispanic, and Caucasian Women. The Journal of Psychology, 134(3), 243-259. https://doi.org/10.1080/00223980009600865

Zerubavel, N., \& Messman-Moore, T. L. (2013). Sexual Victimization, Fear of Sexual Powerlessness, and Cognitive Emotion Dysregulation as Barriers to Sexual Assertiveness in College Women. Violence Against Women, 19(12), 1518-1537. https://doi.org/10.1177/1077801213517566

Received: 2020-06-06

Accepted: 2020-08-12 


\section{Appendix 1}

\section{Main results of the revised studies about Sexual Assertiveness (SA)}

\begin{tabular}{|c|c|c|c|c|}
\hline Author, year & Sample & Instrument used & $\begin{array}{l}\text { Variables/ } \\
\text { categories } \\
\text { studied }\end{array}$ & Main results \\
\hline $\begin{array}{l}\text { Arciniega, G. } \\
\text { M., Tovar- } \\
\text { Blank, Z., } \\
\text { Tracey, T. J., \& } \\
\text { Anderson, T. } \\
\text { (2008) }\end{array}$ & $\begin{array}{l}\text { Study 1: } 154 \\
\text { Mexican men. } \\
\text { Study 2: } 477 \\
\text { American men with } \\
\text { Latino origins; } 403 \\
\text { Mexican Americans } \\
\text { and } 74 \text { Latino non- } \\
\text { Mexican Americans }\end{array}$ & $\begin{array}{l}\text { Study 1: a 71- item Machismo } \\
\text { Measure was designed; The } \\
\text { masculine-Feminine Personality } \\
\text { Traits Scale; Battery of Interpersonal } \\
\text { Capabilities-Short Version; } \\
\text { Satisfaction with life scale. } \\
\text { Study 2: a reduced 20-item } \\
\text { Machismo measure; Multigroup } \\
\text { Ethnic Identity Measure; Toronto } \\
\text { Alexithymia Scale; Shortened Ways } \\
\text { of Coping Questionnaire }\end{array}$ & $\begin{array}{l}\text { Gender stereotypes: } \\
\text { machismo }\end{array}$ & $\begin{array}{l}\text { Machismo was related to } \\
\text { aggressive behavior, greater } \\
\text { levels of alexithymia, and more } \\
\text { wishful thinking as coping } \\
\text { mechanism; it was also related } \\
\text { to less education. Caballerismo } \\
\text { was found to be a positive } \\
\text { variable associated with } \\
\text { affiliation, ethnic identity, and } \\
\text { problem-solving coping }\end{array}$ \\
\hline $\begin{array}{l}\text { Auslander, B. A., } \\
\text { Baker, J., \& } \\
\text { Short, M. B. } \\
\text { (2012) }\end{array}$ & 127 college women & $\begin{array}{l}\text { Body-esteem scale (BESAA; 2001); } \\
\text { Sexual Assertiveness Scale for } \\
\text { Women (SAS; Morokoff et al., 1997) }\end{array}$ & $\begin{array}{l}\text { Body esteem with } \\
\text { sexual } \\
\text { assertiveness (SA) }\end{array}$ & $\begin{array}{l}\text { Body esteem was not related to } \\
\text { SA in terms of initiation and } \\
\text { refusal, but it was found to be } \\
\text { related to condom use. } \\
\text { Individual components of body } \\
\text { esteem did not independently } \\
\text { predict condom use. }\end{array}$ \\
\hline $\begin{array}{l}\text { Auslander, B., } \\
\text { Perfect, M., } \\
\text { Succop, P., \& } \\
\text { Rosenthal, S. } \\
\text { (2007) }\end{array}$ & $\begin{array}{l}106 \text { sexually active } \\
\text { adolescents aged } 14 \\
\text { to } 21 \text { years }\end{array}$ & $\begin{array}{l}\text { Items assessing demographics, } \\
\text { sexual history and behaviors, STDs } \\
\text { and pregnancy, health beliefs, } \\
\text { relationship status; the Sexual } \\
\text { Assertiveness Scale (SAS; Morokoff } \\
\text { et al., 1997); the Mutual } \\
\text { Psychological Development } \\
\text { Questionnaire (MPDQ) }\end{array}$ & $\begin{array}{l}\text { SA with sexual } \\
\text { history and } \\
\text { relationship status. }\end{array}$ & $\begin{array}{l}\text { Initiation SA is not related to the } \\
\text { other dimensions of SA. Having } \\
\text { had a Pregnancy is related to } \\
\text { higher levels of initiation SA. } \\
\text { Greater number of partners was } \\
\text { related to perceptions of less } \\
\text { refusal and less preventive } \\
\text { methods negotiation. }\end{array}$ \\
\hline $\begin{array}{l}\text { Bay-Cheng, L. Y., } \\
\text { \& Eliseo-Arras, } \\
\text { R. K. (2008) }\end{array}$ & $\begin{array}{l}22 \text { undergraduate } \\
\text { women }\end{array}$ & $\begin{array}{l}\text { Interviews; Sexual Life History } \\
\text { Calendar }\end{array}$ & $\begin{array}{l}\text { Refusal SA; sexual } \\
\text { compliance; gender } \\
\text { norms. }\end{array}$ & $\begin{array}{l}\text { Gendered norms such as } \\
\text { passivity and subordination } \\
\text { played important roles in laying } \\
\text { the foundation for unwanted } \\
\text { sex and in negotiation with the } \\
\text { partner. }\end{array}$ \\
\hline $\begin{array}{l}\text { Beres, M. } \\
(2010)\end{array}$ & $\begin{array}{l}11 \text { young women } \\
\text { and } 10 \text { young men }\end{array}$ & In-depth unstructured interviews & Refusal SA & $\begin{array}{l}\text { Tacit knowing, refusing sex, and } \\
\text { active participation are the } \\
\text { aspects that describe } \\
\text { communication of men and } \\
\text { women related to accepting or } \\
\text { refusing sexual proposals. }\end{array}$ \\
\hline $\begin{array}{l}\text { Bourdeau, B., } \\
\text { Thomas, V. K., \& } \\
\text { Long, J. K. } \\
\text { (2008) }\end{array}$ & $\begin{array}{l}155 \text { Latino } \\
\text { adolescents }\end{array}$ & $\begin{array}{l}\text { Demographics: country of origin, } \\
\text { ethnic group; Sexual self-esteem } \\
\text { (Buzwell \& Rosenthal's, 1996); } \\
\text { Sexual self-beliefs; Sexual self- } \\
\text { efficacy; sexual risk-taking }\end{array}$ & $\begin{array}{l}\text { Latino adolescent } \\
\text { sexual identity and } \\
\text { risk taking }\end{array}$ & $\begin{array}{l}\text { Girls are more likely to endorse } \\
\text { needing a commitment to have } \\
\text { sex, expressing anxiety about } \\
\text { being in a sexual situation, and } \\
\text { feeling confident in their ability } \\
\text { to initiate sex. Boys scored } \\
\text { higher in items related to having } \\
\text { high sex drive and expressing } \\
\text { interest in sexual novelty. }\end{array}$ \\
\hline
\end{tabular}




\begin{tabular}{|c|c|c|c|c|}
\hline $\begin{array}{l}\text { Castillo, L. G., } \\
\text { Perez, F. V., } \\
\text { Castillo, R., \& } \\
\text { Ghosheh, M. R. } \\
\text { (2010) }\end{array}$ & $\begin{array}{l}370 \text { Latino female } \\
\text { undergraduate } \\
\text { students }\end{array}$ & $\begin{array}{l}\text { Validation of the Marianismo Beliefs } \\
\text { Scale (MBS); Self Construal Scale; } \\
\text { Acculturation Rating Scale for } \\
\text { Mexican Americans-II (ARSMA-II); } \\
\text { Multiphasic Assessment of Cultural } \\
\text { Constructs-Short form (MACC-SF); } \\
\text { Silencing the Self Scale (STSS) }\end{array}$ & $\begin{array}{l}\text { Gender stereotypes: } \\
\text { marianismo }\end{array}$ & $\begin{array}{l}\text { Validity of the subscales of the } \\
\text { Marianismo Belief Scale was } \\
\text { confirmed (family pillar; } \\
\text { virtuous and chaste; } \\
\text { subordinate to others; silencing } \\
\text { self to maintain harmony; } \\
\text { spiritual pillar). There was no } \\
\text { association between marianismo } \\
\text { and acculturation. }\end{array}$ \\
\hline $\begin{array}{l}\text { Fetterolf, J. C., } \\
\text { \& Sanchez, D. } \\
\text { T. }(2015) .\end{array}$ & $\begin{array}{l}\text { Study 1: } 115 \text { men } \\
\text { and } 120 \text { women, } \\
\text { mean age } 19 \text { years. } \\
\text { Study } 2: 67 \text { men and } \\
57 \text { women }\end{array}$ & $\begin{array}{l}\text { Study 1: } 20 \text {-min study in a } \\
\text { psychology laboratory about the } \\
\text { effects of peripheral cues on } \\
\text { perceptions of dating profiles. } \\
\text { Study } 2 \text { : short survey about agentic } \\
\text { desirable partner. }\end{array}$ & $\begin{array}{l}\text { SA; Sexual agency; } \\
\text { gender }\end{array}$ & $\begin{array}{l}\text { Sexual is understood in a } \\
\text { different way for men and } \\
\text { women. Women may be } \\
\text { penalized and stigmatized for } \\
\text { sexual agency. Women are less } \\
\text { likely to communicate desires } \\
\text { and initiate sex. }\end{array}$ \\
\hline $\begin{array}{l}\text { Gambrill, E. D., } \\
\text { \& Richey, C. A. } \\
\text { (1975). }\end{array}$ & $\begin{array}{l}\text { Undergraduate } \\
\text { students: } 269 \text { men } \\
\text { and } 407 \text { women }\end{array}$ & $\begin{array}{l}\text { A } 40 \text {-item assertion inventory for } \\
\text { use in Assessment Research (it } \\
\text { addresses questions about sexual } \\
\text { contexts for assertiveness) }\end{array}$ & $\begin{array}{l}\text { General } \\
\text { Assertiveness }\end{array}$ & $\begin{array}{l}\text { The Assertion inventory appears } \\
\text { to be useful clinically and in the } \\
\text { investigation of group } \\
\text { differences. Men had higher } \\
\text { scores than women, i.e., were } \\
\text { more assertive. }\end{array}$ \\
\hline $\begin{array}{l}\text { Goicolea, I., } \\
\text { Torres, M. S., } \\
\text { Edin, K., \& } \\
\text { Öhman, A. } \\
\text { (2012). }\end{array}$ & $\begin{array}{l}\text { Data set } 1: 8 \text { young } \\
\text { woman; data set } 2: \\
36 \text { health care } \\
\text { providers; data set } 3: \\
24 \text { young men; data } \\
\text { set } 4: 11 \text { activist } \\
\text { young men }\end{array}$ & $\begin{array}{l}\text { Data set 1: interviews; data set 2: } \\
\text { interviews and focus groups; data } \\
\text { set } 3 \text { : interviews and focus groups; } \\
\text { data set } 4 \text { : interviews. }\end{array}$ & $\begin{array}{l}\text { Age and gender } \\
\text { with SA. }\end{array}$ & $\begin{array}{l}\text { The construction of sexuality in } \\
\text { Ecuador is framed by five } \\
\text { repertoires that shows the } \\
\text { hierarchy of sexualities: } \\
\text { importance of becoming } \\
\text { sexually respectable women; } \\
\text { policing young women's } \\
\text { sexuality; men threatening and } \\
\text { protecting women; sexual } \\
\text { relations (fooling, seducing, } \\
\text { abusing); emerging resistance. }\end{array}$ \\
\hline $\begin{array}{l}\text { Gratz, K. L., \& } \\
\text { Roemer, L. } \\
(2004) .\end{array}$ & $\begin{array}{l}\text { Study 1: } 357 \\
\text { undergraduate } \\
\text { students in USA. } \\
\text { Study 2: } 194 \\
\text { undergraduate } \\
\text { students }\end{array}$ & $\begin{array}{l}\text { Difficulties in emotion regulation } \\
\text { scale (DERS); Generalized } \\
\text { Expectancy for Negative Mood } \\
\text { Regulation Scale (NMR; Catanzaro \& } \\
\text { Mearns, 1990); Acceptance and } \\
\text { Action Questionnaire (AAQ); } \\
\text { Emotional Expressivity Scale (EES; } \\
\text { Kring, Smith, \& Neale, 1994); } \\
\text { Deliberate Self-Harm Inventory } \\
\text { (DSHI; Gratz, 2001); The Abuse- } \\
\text { Perpetration Inventory (API; Lisak, } \\
\text { Conklin, Hopper, Miller, Altschuler, } \\
\text { \& Smith, 2000). }\end{array}$ & $\begin{array}{l}\text { Emotion regulation/ } \\
\text { dysregulation }\end{array}$ & $\begin{array}{l}\text { The existence of six separate } \\
\text { dimensions of emotion } \\
\text { regulation: lack of awareness; } \\
\text { lack of clarity; non-acceptance; } \\
\text { limited access to strategies } \\
\text { perceived as effective; } \\
\text { difficulties controlling impulses } \\
\text { when experiencing negative } \\
\text { emotions; difficulties engaging } \\
\text { in goal-directed behaviors when } \\
\text { experiencing negative emotions. }\end{array}$ \\
\hline $\begin{array}{l}\text { Greene, K., \& } \\
\text { Faulkner, S. L. } \\
\text { (2005). }\end{array}$ & 698 couples & $\begin{array}{l}\text { Sexual Self-Disclosure Scale (SDSS; } \\
\text { Herold \& Way, 1988); Dyadic Sexual } \\
\text { Communication scale (DSC; Catania } \\
\text { et al., 1992); Dyadic Sexual } \\
\text { Regulation scale (DSR; Catania et al., } \\
\text { 1992); Double Standard Scale } \\
\text { (Caron, Davis, Halteman, \& Stickle, } \\
\text { 1993); Hurlbert Index of Sexual } \\
\text { Assertiveness (HISA; Hurlbert, 1991). }\end{array}$ & $\begin{array}{l}\text { SA; Double } \\
\text { Standard, sexual } \\
\text { scripts }\end{array}$ & $\begin{array}{l}\text { Women reported more dyadic } \\
\text { sexual negotiation, but less } \\
\text { efficacy than their male } \\
\text { partners; individuals with less } \\
\text { traditional attitudes and gender } \\
\text { roles discussed more about } \\
\text { sexual issues and disclosed } \\
\text { more information with their } \\
\text { partners. Sexual assertiveness is } \\
\text { also associated with relationship } \\
\text { satisfaction. }\end{array}$ \\
\hline Hirst, J. (2008). & $\begin{array}{l}11 \text { female } \\
\text { adolescents }\end{array}$ & Focus groups and interviews & SA with Education & $\begin{array}{l}\text { Sex education focused on sexual } \\
\text { competence may result in } \\
\text { better autonomy and the } \\
\text { development of safer sex skills } \\
\text { (condom use, influence of peer } \\
\text { practices). }\end{array}$ \\
\hline
\end{tabular}




\section{Humphreys, T. 330 female, P., \& Kennett, D. undergraduate} J. (2010). students

Impett, E. A.,

Schooler, D., \&

Tolman, D. L.

(2006).

Kelley, E. L., Orchowski, L. M., \& Gidycz, C. A. (2016).

Kennett, D. J., Humphreys, T. P., \& Schultz, K. E. (2012).

Kitzinger, C., \& Frith, H. (1999).

Leclerc, B. Bergeron, S., Brassard, A., Bélanger, C., Steben, M., \& Lambert, B. (2015).

Livingston, J. A. Testa, M., \&
VanZile-Tamsen, C. (2007).

116 female adolescents

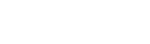
women and university students

101 couples
296 college women Semographics; Sexual Experiences Survey (SES; Koss \& Oros, 1982); Sexual Assertiveness Questionnaire for Women (SAQ-W; MessmanMoore et al., 2007); The Resistance Self-efficacy rating Scale (Marx et al., 2001); The Psychological Barriers to Resisting Questionnaire (PBRQ; Norris et al., 1996)

178 undergraduate

The SCS; The Sexual Resourcefulness Inventory; The Reasons for Consenting to Unwanted Sexual Advances Inventory (RFC); The Sexual Self-Efficacy Scale; The Sexual Giving-in Experiences Survey, a revised version of the SATAQ-3

58 female schools

1014 young women

Focus groups;

Tape recorded interactions

Horizontal analog scale for pain; Experiences in Close Relationships Scale-Revised (ECR-R; Fraley, Waller, \& Brennan, 2000); The Hurlbert Index of Sexual Assertiveness (HISA; Hurlbert, 1991); Female Sexual Function Index (Rosen et al., 2000); Sexual History Form (SHF; Nowinski \& LoPiccolo, 1979); The Global Measure of Sexual Satisfaction (GMSEX; Lawrance and Byers, 1995) Sexual Experiences survey (SES; Koss, Gidycz, \& Winiewski, 1987); Sexual Assertiveness Scale (Morokoff, et al., 1997); items for depression symptoms; Post traumatic stress disorder items.
Resourcefulness; victimization experiences; Refusal SA

Femininity ideology, sexual self-efficacy, sexual experiences, protection behavior

Sexual

Victimization

\section{Resourcefulness;} Refusal SA

Refusal SA; gender

Attachment, pain, sexual function, sexual satisfaction and SA

SA and violence
Process of regulating emotions, sexual self-efficacy, reasons for consenting predict resourcefulness and hence predict consenting to unwanted sexual behavior (refusal SA).

Inauthenticity in relationship and body objectification were associated with poorer sexual self-efficacy and thus it predicted less sexual experience and less use of protection. Two components of femininity ideology were associated with different forms of protection.

Relational SA served as a salient mechanism of the victimization revictimization relationship. Increasing women's sexual assertiveness skills may be a particular important component of reducing risk for sexual revictimization.

Receiving more information from the mother about dealing with unwanted sexual advances emerges as direct contributor for resourcefulness. Higher learned resourcefulness is associated with fewer consenting unwanted sexual advances.

Explicit refusals of sex have negative implications for women. Women rely to the use of excuses to say no, delay acceptance of proposals or offer palliatives in refusing sex.

Partner effects indicated higher sexual assertiveness in women and predicted higher sexual satisfaction in men. Women's SA was found to be a significant mediator of the relationship between their attachment dimensions, sexual function and satisfaction.

There is a reciprocal relationship between history of victimization with SA and between SA and the possibility of subsequent victimization. 


\begin{tabular}{ll}
\hline Loshek, E., \& & Study 1: 209 female \\
Terrell, H. K. & college students. \\
(2014). & Study 2: 516 female \\
& college students.
\end{tabular}

Manago, A. M., Ward, L. M., Lemm, K. M. Reed, L., \& Seabrook, R. (2015)

Manago, A. M Ward, L. M., \& adults in college Aldana, A. (2015).

McNicoll, G., Corsini-Munt, S., Rosen, N. O., McDuff, P., \& Bergeron, $\mathrm{S}$. (2016).

Ménard, A. D., \& Offman, $A$. (2009).

104 women with PVD symptomatology men undergraduate students

Study 1: The Sexual Assertiveness Questionnaire (SAQ) was designed and tested.

Study 2: adapted/revised version of the SAQ.

Items assessing Facebook use peer day, passive and active use; Facebook Intensity Scale (Ellison et al. 2007); the Gordon and Ward SelfWorth Measure (2000); the Objectified Body Consciousness Scales - Youth (OBC Y Lindberg et al., 2006); The Enjoyment of Sexualization Scale (Liss et al., 2011); 5-item Shame subscale of the OBCY; Lindberg et al., 2006); Hurlbert Index of Sexual Assertiveness (HISA; Hurlbert, 1991).

A 29-item version of the Sexual Socialization Discourses Measure (Kim \& Ward, 2007); Hurlbert Index of Sexual Assertiveness (HISA; Hurlbert, 1991)

Demographics; Spouse Response Inventory (SRI); Hurlbert Index of Sexual Assertiveness (HISA; Hurlbert, 1991); Female Sexual Function Index (FSFI; Rosen et al., 2000); The Global Measure of Sexual Satisfaction (GMSEX; Lawrance \& Byers, 1998).

Index of Sexual Satisfaction (Hudson et al., 1981), Sexual Assertiveness Scale, The sexual self-esteem scale (Zeanah and Schwarz, 1996)

Morokoff, P. J., Quina, K., Harlow, L. L., Whitmire, L., Grimley, D. M. Gibson, P. R., \& Burkholder, G. J. (1997).
25 men and 46 women, mean age 27.65 years
Study 1: 260 undergraduate female students. Study 2 used the same sample as study 1.

Study 3: 714 women Study 4: 354 women
The Sexual Assertiveness Scale (SAS) was designed and tested; The Social desirability subscale of the Jackson Personality Research Form (Jackson, 1984); the Relationship Satisfaction Scale (Roach, Frazier and Bowden's, 1981); More say in the relationship scale (Celebucki, 1990); Sexual Victimization Scale (Koss \& Oros, 1982); Sexual Experience Scale. Items regarding anticipated negative partner response, self-efficacy STDpreventive behaviors, childhood sexual abuse.

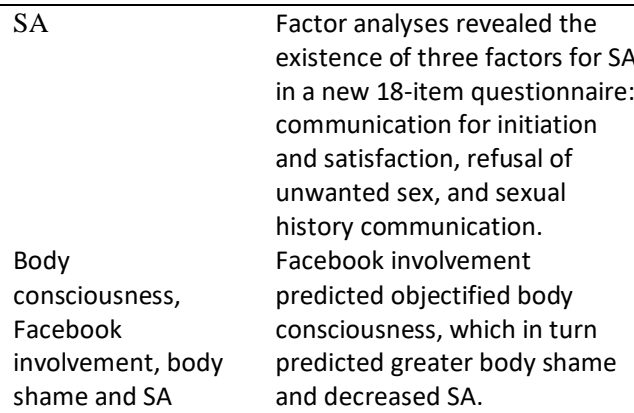

Factor analyses revealed the existence of three factors for SA in a new 18-item questionnaire: communication for initiation and satisfaction, refusal of unwanted sex, and sexual history communication. Facebook involvement predicted objectified body consciousness, which in turn predicted greater body shame and decreased SA.

Gender stereotypes, family messages, SA

Sexual function, SA, sexual satisfaction.

Sexual self-esteem, SA and sexual satisfaction

$\mathrm{SA}$, relationship satisfaction, sexual victimization
Prevalence of four types of messages they heard from parents and friends: sex is only for marriage (family messages), sex is only appropriate in a loving relationship (family messages), sex is for pleasure (peer messages) and sexual double standard. There are strong gender differences in the mentioned sex messages.

Higher levels of SA mediated the associations between greater perceived facilitative partner responses to pain and higher levels of sexual function and satisfaction.

Sexual assertiveness has been shown to be a partial mediator of the relationship between sexual self-esteem and sexual satisfaction.

SA comprised three factors: Initiation, Refusal and Greater woman's sexual experiences is associated with greater self-reported ability to initiate sex. Sexual experience, anticipated partner response and self-efficacy predict SA. SA is associated with relationship satisfaction. Pregnancy STD-prevention. 
Morokoff, P Redding, C. A., Harlow, L. L., Cho, S., Rossi, J.

S., Meier, K. S.

Brown-

Peterside, $P$.

(2009).

Noar, S. M.,

Carlyle, K., \&

Cole, C. (2006).

Noar, S. M., Morokoff, P. J., \& Harlow, L. L. (2002).

Onuoha, F. N.,

\& Munakata, T. (2005).

Raffaelli, M., \& Ontai, L. L. (2004)

Rickert, V. I., Sanghvi, R., \& Wiemann, C. M. (2002).
471 undergraduate students, men and women
473 heterosexually active adult men and women

53 articles

1029 male and 928

female

undergraduate students from four countries

Study 1: 22 adult Latinas

Study 2: 166 Latino/a college students
Demographics and risk related items; Sexual Victimization Scale (Koss \& Oros, 1982); Depression Symptoms Index (short form) (Kohout, et al., 1993); Subscale of condom negotiation of the SAS (Morokoff et al., 1997).

Literature review

Condom influence strategy questionnaire (CISQ) designed; Sexual Assertiveness Scale (SAS) (Morokoff, et al., 1997); Partner communication items (Redding et al., 2001); Condom Self-Efficacy (Redding and Rossi, 1999); Negotiation Self-Efficacy (Bryan et al., 1997), items for social desirability, condom use and sexual experience.

The Rathus Assertiveness Schedule (Groth-Marnat, 1997); sexual assertiveness items (St. Lawrence, 1988); sexual health assertiveness and HIV items (Painter, 1987).

Study 1: In-depth interviews. Study 2: self-report surveys; items related to gender role socialization; Attitudes Toward Gender Scale (Leaper, 1993).
Demographics, reproductive questions regarding the variables: contraceptive use and high-risk sexual behavior, lifetime physical or sexual violence and perceived sexual assertiveness.

Demographics; the Rathus Assertiveness Schedule

Sexual
victimization,
depression,
Condom use
negotiation SA

SA, condom use, sexual experiences.

General

Assertiveness, SA

Sexual socialization within family of origin; romantic and sexual experiences
General

Assertiveness; demographics
The tested model predicts unprotected sex in both at-risk men and women. SA, sexual victimization and depression were tested as mediators of condom SA and unprotected sex. Condom SA was found in both genders to predict later sexual victimization. Communication about condom use, sexual history were important variables found in the literature

There is the influence of six strategies used by men and women to persuade partners to use condoms: withholding sex, direct request, seduction, relationship contextualization, risk information, deception. These strategies confirmed the subscales of the CISQ designed for this study. The CISQ was related to $\mathrm{SA}$.

Social and sexual assertiveness have commonalities, but there are certain differences as their correlation is low.

Gender and cultural differences were shown in this study. Latino parents socialize their daughters in ways that are marked by "traditional" genderrelated expectations. Men and women described different experiences of household activities, socialization of gender-typed behavior, and freedom to pursue social activities or gain access to privileges. Characteristics of parents were linked to genderrelated socialization.

Contraceptive methods Sexually assertive beliefs, behaviors and practices are important for the development of sexual health during adolescence. A considerable group of respondents have shown to be in high risk, do not perceive rights to refuse, to ask the partner to test for STDs.

Significant differences existed between levels of assertiveness and academic classification and ethnicity.
87 female college Johnson, S. W., students

(2001). active adolescents

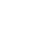




\begin{tabular}{|c|c|c|c|c|}
\hline $\begin{array}{l}\text { Sánchez-Bravo, } \\
\text { C., Morales- } \\
\text { Carmona, F., } \\
\text { Carreño- } \\
\text { Meléndez, J., \& } \\
\text { Martínez- } \\
\text { Ramírez, S. } \\
\text { (2005). }\end{array}$ & 200 female adults & $\begin{array}{l}\text { Female Sexuality clinical history; } \\
\text { masculinity-femininity inventory; } \\
\text { multidimensional scale of } \\
\text { Assertiveness }\end{array}$ & $\begin{array}{l}\text { Sexual functioning; } \\
\text { assertiveness }\end{array}$ & $\begin{array}{l}\text { Gender role, submission, } \\
\text { indirect assertiveness and low } \\
\text { levels of assertiveness are } \\
\text { directly associated to } \\
\text { unsatisfactory sexual } \\
\text { functioning. }\end{array}$ \\
\hline $\begin{array}{l}\text { Santos-Iglesias, } \\
\text { P., \& Sierra, J. } \\
\text { C. (2010). }\end{array}$ & 76 articles & Literature review & SA & $\begin{array}{l}\text { SA is a positively related to } \\
\text { sexual functioning, is a } \\
\text { protective factor for sexual } \\
\text { abuse and victimization } \\
\text { experiences and for engaging in } \\
\text { risky sexual encounters. }\end{array}$ \\
\hline $\begin{array}{l}\text { Santos-Iglesias, } \\
\text { P., \& Sierra, J. } \\
\text { C. (2012). }\end{array}$ & 402 college women & $\begin{array}{l}\text { Demographics; Refusal sub-scale of } \\
\text { the Sexual Assertiveness Scale (SAS; } \\
\text { Morokoff, et al., 1997); items } \\
\text { regarding sexual experiences, } \\
\text { substance use prior to sex; the } \\
\text { Sexual victimization subscale of the } \\
\text { Juvenile Victimization Questionnaire } \\
\text { (Pereda, Gallardo-Pujol, \& Forero, } \\
\text { 2008); The Sexual Experiences } \\
\text { Survey (SES; Koss \& Oros, 1982). }\end{array}$ & $\begin{array}{l}\text { SA, sexual } \\
\text { victimization }\end{array}$ & $\begin{array}{l}\text { Victims of child sexual abuse } \\
\text { scored lower levels of SA and } \\
\text { higher number of partners. } \\
\text { Around } 30 \% \text { of women engaged } \\
\text { in undesired sexual contact and } \\
4 \% \text { were victims of rape }\end{array}$ \\
\hline $\begin{array}{l}\text { Santos-Iglesias, } \\
\text { P., Sierra, J. C., } \\
\text { \& Vallejo- } \\
\text { Medina, P. } \\
(2013) .\end{array}$ & $\begin{array}{l}1619 \text { men and } 1755 \\
\text { women aged } 18-87 \\
\text { years }\end{array}$ & $\begin{array}{l}\text { Demographics; Hurlbert Index of } \\
\text { Sexual Assertiveness (HISA; Hurlbert, } \\
\text { 1991); Sexual Opinion Survey (SOS; } \\
\text { Fisher, Byrne,White,\& Kelley, 1988); } \\
\text { Hurlbert Index of Sexual Fantasy } \\
\text { (Hurlbert \& Apt, 1993); Sexual } \\
\text { Desire Inventory (Spector, Carey, \& } \\
\text { Steinberg, 1996); Index of Spouse } \\
\text { Abuse (Hudson \& McIntosh, 1981). }\end{array}$ & $\begin{array}{l}\text { SA, sexual } \\
\text { attitudes, sexual } \\
\text { functioning; } \\
\text { attitudes towards } \\
\text { sex fantasies; } \\
\text { dyadic desire }\end{array}$ & $\begin{array}{l}\text { Higher levels of SA was } \\
\text { predicted by lower frequency of } \\
\text { partner abuse, positive attitudes } \\
\text { towards fantasies and } \\
\text { erotophilia, higher sexual } \\
\text { arousal and higher dyadic } \\
\text { desire. }\end{array}$ \\
\hline $\begin{array}{l}\text { Santos-Iglesias, } \\
\text { P., Vallejo- } \\
\text { Medina, P., \& } \\
\text { Sierra, J. C. } \\
\text { (2013). }\end{array}$ & $\begin{array}{l}1600 \text { women and } \\
1598 \text { men }\end{array}$ & $\begin{array}{l}\text { Hurlbert Index of Sexual } \\
\text { Assertiveness (HISA; Hurlbert, 1991) }\end{array}$ & SA & $\begin{array}{l}\text { Measurement invariance and } \\
\text { differential item functioning of } \\
\text { the Spanish version of the HISA } \\
\text { showed weak measurement } \\
\text { invariance. The HISA is not } \\
\text { recommended to compare } \\
\text { levels of SA between sexes. }\end{array}$ \\
\hline $\begin{array}{l}\text { Sastre, F., Rosa, } \\
\text { M. D. L., Ibanez, } \\
\text { G. E., Whitt, E., } \\
\text { Martin, S. S., \& } \\
\text { O'Connell, D. J. } \\
\text { (2015). }\end{array}$ & $\begin{array}{l}67 \text { young Latino men } \\
\text { and women }\end{array}$ & Focus groups & $\begin{array}{l}\text { Machismo, } \\
\text { marianismo, and } \\
\text { condom } \\
\text { negotiation SA }\end{array}$ & $\begin{array}{l}\text { Condom use negotiation is } \\
\text { influenced by attitudes and } \\
\text { behaviors that counter } \\
\text { traditional gender roles towards } \\
\text { sex and expected sexual } \\
\text { behaviors informed by } \\
\text { machismo and marianismo. }\end{array}$ \\
\hline $\begin{array}{l}\text { Schry, A. R., \& } \\
\text { White, S. W. } \\
\text { (2013). }\end{array}$ & 672 college women & $\begin{array}{l}\text { The Social Interaction Anxiety Scale } \\
\text { (SIAS; Mattick \& Clarke, 1998); The } \\
\text { Sexual Experiences Survey-Short } \\
\text { Form Victimization (SES-SFV; Koss et } \\
\text { al., 2007); Refusal subscale of the } \\
\text { Sexual Assertiveness Scale (SAS; } \\
\text { Morokoff et al., 1997); one item } \\
\text { assessing childhood victimization } \\
\text { experiences. }\end{array}$ & $\begin{array}{l}\text { Social interaction } \\
\text { anxiety, SA and } \\
\text { sexual victimization }\end{array}$ & $\begin{array}{l}\text { Social interaction anxiety was } \\
\text { found to be related to likelihood } \\
\text { of experiencing coerced sexual } \\
\text { intercourse and decreased } \\
\text { refusal SA }\end{array}$ \\
\hline
\end{tabular}


Articles

Connolly, J.

(2013).

Tolman, D. L., Davis, B. R., \& Bowman, C. P. (2016).

Torres-Obregon,

R., Onofre-

Rodríguez, D.

J., Sierra, J. C.

Benavides-

Torres, R. A., \&

Garza-Elizondo,

M. E. (2017)

Vannier, S. A.,

\& O'Sullivan,

L. F. (2011).
Study 1: 250 male and female adolescents. Study 2: 53 female adolescents

32 women and 31

Yoshioka, M. (2000). men involved in committed

relationships

202 adult women aged $18-40$ years

115 women of three

different countries
Literature review

Study 1: The Adolescent Femininity Ideology Scale (AFIS; Tolman, Impett, Tracy, \& Michael, 2006;

Tolman \& Porche, 2000); The Adolescent Masculinity Ideology in Relationships Scale (AMIRS; Chu et al., 2005); items about convention in heterosexual relationships and regarding boy's endorsement of male coercion.

Study 2: interviews.

Sexual Assertiveness Scale (SAS Morokoff et al., 1997); Depression inventory (IDER; Spielberger, Buela-Casal y Agudelo, 2008)

Structured daily diaries

Role plays
General

Assertiveness

Femininity and masculinity ideologies

SA, Depression

Verbal and nonverbal ways of communication to initiate sex.

SA; Cognitive emotion dysregulation; fear of powerlesness
It is proposed a transitional emerging adult romantic stage in which individuals need to coordinate life plans to each other, integrate career paths and life plans. Resolution of this state leads a possibility of longterm commitment to a life partner.

Gender ideologies constitute a key structure of institutionalized heterosexuality which leads to a gendered hierarchy in relationships for boys and girls. This hierarchy between boys and girls seems to reinforce gender inequalities.

Factorial structure and validity of the SAS was tested and proved.

Depression was found to be associated with low levels of SA.

Men's and women's behavior is shaped by traditional gender roles in which men initiate and women restrict sexual activity. Nonverbal messages were used both by men and women but the type of messages were different.

There are substantial differences in terms of what constitutes passive, assertive and aggressive responses. There are differences in perceptions of assertiveness among cultures.

Sexually victimized women had greater problems with SA, fear of powerlessness and cognitive emotion dysregulation compared to non-victims.

Moore, T. L.

(2013).

(SAQ; Messman-Moore et al., Sexual Self-Esteem Inventory for Women Short Form (SSEI-W-S Zeanah \& Schwarz, 1996); Difficulties in Emotion Regulation Scale (DERS; Gratz \& Roemer, 2004); Sexual Experiences Survey (SES; Koss et al., 1987). 